\title{
Character transformations and their functional significance as a key to the evolution of hystricognath Rodentia ${ }^{1}$
}

\author{
Andrea Mess ${ }^{2 *}$
}

\begin{abstract}
Mess A. 2011. Character transformations and their functional significance as a key to the evolution of hystricognath Rodentia. Pesquisa Veterinária Brasileira 31(12):1108-1115. Department of Research, Museum of Natural History, Humboldt-University Berlin, Invalidenstr. 43, D-10115 Berlin, Germany. E-mail: drandrmss@aol.com

Hystricognathi represent a monophyletic taxon within Rodentia. Since phylogenetically analyzed morphological systems are essential for revealing evolutionary processes, this study identifies evolutionary character transformations on the stem lineage of Hystricognathi as derived from the author's own work and the literature. Data so far indicate that evolutionary transformations in the rostral head region, the loss of tactile ability in the outer nasal skin and the mobile arrangement of the associated cartilage, were allied with a switch from omnivorous to herbivorous and fiber-rich nutrition. Additional character transformations in the skull assist in digesting such food. Structures associated with reproduction and placentation show a remarkable proportion of derived character conditions: the chorioallantoic placenta has a ring-shaped organization and growth structure which optimizes the capacity for passive diffusion, a subplacenta occurred as a specialized region responsible for placental invasion and the inverted yolk sac facilitates substance exchange with the main placenta. Finally, precocial newborns evolved as a derived condition within Rodentia. All things considered, a mode of reproduction is indicated, which does not demand excessive additional energy intake by the mother and is in accordance with her low energetic diet. Hystricognathi possess major character transformations that represent prerequisites for their successful radiation at the time when more open ecosystems and grasslands evolved during Earth history. The analysis resulted in the reconstruction of a life-near picture of the hystricognath stem species pattern with high explanatory power in terms of changes in space and time and their interdependence with biodiversity.
\end{abstract}

INDEX TERMS: Hystricognathi, Caviomorpha, functional morphology, organismal biology, phylogeny.

\section{BACKGROUND ON HYSTRICOGNATH EVOLUTION}

Hystricognathi is a high-level taxon within Rodentia, first recognized by the Swedish zoologist Tycho Tullberg (1899). These rodents obtained much attention because of their enigmatic biogeographical history with a disjunct distribution in (South-) America on the one hand and Africa and Asia on the other (George 1993, Wilson \& Reeder 2005). The fossil record goes back to the Late Eocene in both Africa and South America (Jaeger et al. 1985, Campell et al. 1996; see Mess et al. 2001). An impressive radiation occurred from the Eocene-Oligocene time interval on (e.g. Wood \& Patter-

\footnotetext{
${ }^{1}$ Received on June 6, 2011.

Accepted for publication on September 10, 2011

${ }^{2}$ Department of Research, Museum of Natural History, Humboldt-University Berlin, Invalidenstr. 43, D-10115 Berlin, Germany. *Corresponding author: drandrmss@aol.com
}

son 1959, Patterson \& Wood 1982, Wyss et al. 1993, Winkler 1994, McKenna \& Bell 1997, Flynn \& Wyss 1998, Vucetich \& Verzi 1999, Vucetich et al. 1999, Sánchez-Villagra et al. 2003, Rinderknecht \& Blanco 2008), associated with global cooling and a shift of the vegetation towards more open ecosystems such as temperate forests or wooded savannah formations (Mess et al. 2001). Most remarkably, the origin and radiation of hystricognaths has taken place when South America was entirely isolated from other continents (Tarling 1980, George 1993, Flynn \& Wyss 1998). A parallel is recognized for the New World primates (Chiochon \& Chiarelli 1980, Martin 1990). Thus, accepting hystricognaths as a monophyletic assemblage implies the necessity of recognizing remarkable migration routes, such as crossing the South Atlantic Ocean from Africa to South America by drifting or island hopping (Lavocat 1969, 1980) or colonization of South America via Australia and Antartica from an Asian origin (Huchon 
and Douzery 2001). In view of the geographical disruptiveness, a long lasting dispute came about in the last century, if hystricognaths in fact represent a monophyletic taxon in the context of phylogenetic systematics or not (overview in Luckett \& Hartenberger 1985). However, no other group of Rodentia was ever proven phylogenetically as sister group to one of the geographical groups or any other subgroup of hystricognaths (Luckett and Hartenberger 1985). Recently, Hystricognathi is supported as a monophyletic taxon primarily by molecular data sets (Nedbal et al. 1994, 1996, Catzeflis et al. 1995, Huchon et al. 1999, 2000, Huchon \& Douzery 2001; see Sullivan \& Swofford 1997). Morphological systems were in general not properly examined by modern phylogenetic or cladistic approaches. Since phylogenetically analyzed morphological systems are of great importance for revealing evolutionary processes and significant for the biology and ecology of organisms, the present study provides a comprehensive overview of morphological systems that have been regarded as relevant for supporting Hystricognathi. Evolutionary character transformations on their stem lineage are identified, as derived from the author's own work and the literature, and their functional significance were discussed in regard to the group's evolutionary history. The analysis includes systems commonly used for mammalian phylogenetics such as skeleton, teeth and musculature. Main attention is drawn to an unusual system, the placenta and the fetal membranes, which resulted as most important in the above mentioned regard.

\section{RELEVANCE OF MORPHOLOGICAL SYSTEMS FOR HYSTRICOGNATHI}

\section{Lower jaw and associated musculature}

In Tullberg's influential study, Rodentia were divided by differences in the dental bone (see Fig.1) into two clades, Hystricognathi and Sciurognathi. In hystricognaths the pro- cessus angularis is situated on the lateral surface of the dental and the ventral border of the process, the margo inferior, is in parallel to the zygomatic arch (Tullberg 1899, Fig.1B). In addition, the pars reflexa of the m. pterygoideus lateralis superficialis is located on the median surface of the processus angularis and inserts in an incisura praeangularis towards the corpus mandibulae (Tullberg 1899, Starck 1995). In sciurognaths the processus angularis is located at the ventral border of the dental and curved to the inside, with an evident incline between the Margo inferior and the zygomatic arch (Tullberg 1899, Fig.1A). As a rule, the m. pterygoideus lateralis superficialis is restricted to the outside of the processus angularis and inserts on its margo inferior. In a few sciurognaths small portions of the muscle are sited median, but not in the pattern of a prominent pars reflexa (Tullberg 1899). To employ the structures concerned in modern phylogenetics causes some difficulties: Ctenodactylidae, a group originally belonging to Sciurognathi, share some characteristics of the hystricognath condition (Tullberg 1899, Mess 1997). Moreover, the conditions of the lower jaw differ from that of other mammals and thus, the character polarity cannot be established by out-group comparison (Mess 1997). However, a sciurognath lower jaw occurs in early fossils of Rodentia, indicating that the hystricognath condition is derived (Luckett \& Hartenberger 1985, Landry 1999). A derived state is also assumed for the pars reflexa (Mess 1997, Landry 1999). While these features are revealed as synapomorphies of Hystricognathi (plus Ctenodactylidae), the functional significance is enigmatic. Yet, it may be linked with the hystricognath chewing pattern that is characterized by a pronounced propalinal (fore- and backward) gliding of the teeth surfaces.

\section{Maxillare and M. masseter medialis}

Some authors speak of a "hystricomorph" condition of the skull, i.e. the enlargement of the foramen infraorbitale of

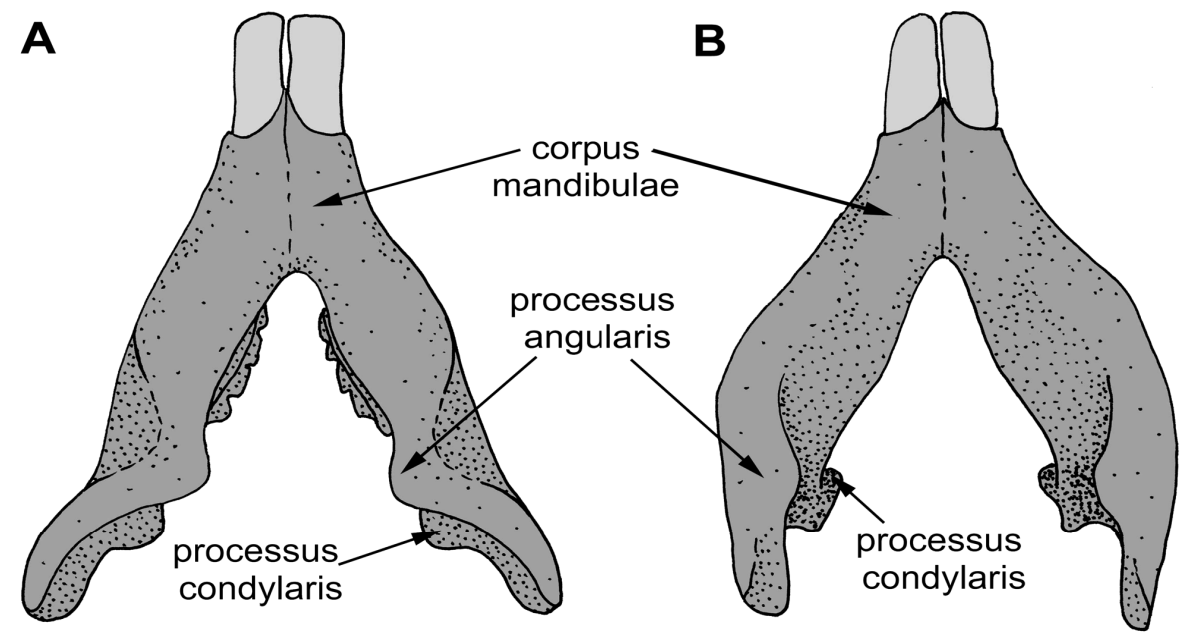

Fig.1. The lower jaw in rodents. (A) The sciurognath condition. It represents the ancestral condition of Rodentia. The processus angularis is located at the ventral border of the dental bone. It curved to the inside with an evident incline to the zygomatic arch. (B) The hystricognath lower jaw. It is a derived character condition within rodents that evolved on the stem lineage of Hystricognathi. The processus angularis is situated on the lateral surface of the dental. Its ventral border is in parallel to the zygomatic arch. Derived from Tullberg (1899) and other authors. 
the maxillare for the insertation of the m. masseter medialis. It occurs in all Hystricognathi except some members of Bathyergidae. However, the later are hystricomorph in early ontogeny but lose this condition during growth (Maier \& Schrenk 1989). Originally introduced by Waterhouse (1848) and Brandt (1855), four conditions are currently recognized: the myomorph one has also an association of the $m$. masseter medialis with an enlarged foramen infraorbitale, but the $m$. masseter lateralis inserts rostrally at the outside of the maxillare ("Sciuridenplatte"). In the sciuromorph and protrogomorph conditions the foramen infraorbitale is small without an association to musculature. In the first, a rostral insertation of the m. masseter lateralis is present, whereas the later is not specialized. Though the protrogomorph condition is similar to that of other mammals and certainly is plesiomorphic for rodents, the character polarity of the other forms is not resolved. They do not represent separated conditions in the phylogenetic sense and must be the result of convergences. Finally, the hystricomorph condition is shared with numerous other groups. In conclusion, this complex is not valuable to support Hystricognathi.

\section{Other skull components}

In all hystricognaths except adult Hydrochaeris, the fossa pterygoidea breaks through into the orbita (Fig.2) and the $m$. pterygoideus internus inserts at the skull base or in

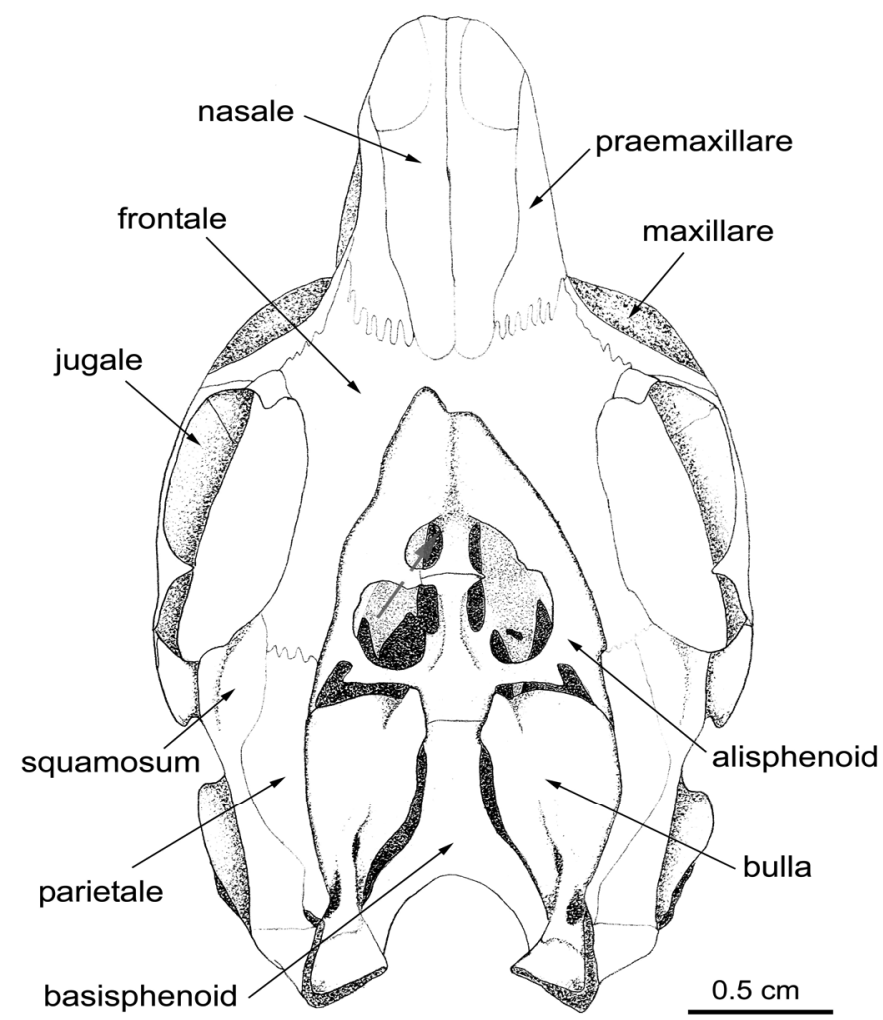

Fig.2. The skull of a South American hystricognath, Octodon degus. As typical for hystricognaths, the fossa pterygoidea breaks through into the orbita (red arrow). This represents a derived character condition that evolved on the stem lineage of Hystricognathi. In the ancestral condition of Rodentia the fossa is closed towards the orbita. the orbit (Tullberg 1899, Landry 1957, 1999). An analogous formation is present in Spalax and some geomyids, whereas in other rodents the fossa pterygoidea is closed and served for the insertion of the $m$. pterygoideus internus (Tullberg 1899). Since the usual condition in mammals resembles the later, the hystricognath condition is apparently derived (see Landry 1999). The functional significance is yet not entirely resolved, but this feature may be associated to the propalinal mode of chewing (Landry 1999). In addition, the lacrimal foramen of hystricognaths and ctenodactylids is positioned posterior and medial in relation to the incisor and the nasolacrimal duct runs ventral or medial to the tooth, regarded as a derived condition compared with the ancestral or plesiomorphic state of Rodentia, represented by an anterior and lateral position of the duct (Frahnert 1999, Landry 1999). This shift may be linked with the anterior location of the m. masseter (Frahnert 1999). Finally, two of the inner ear bones, the malleus and incus, are fused or at least closely joined in hystricognaths and ctenodactylids, whereas they are separated in other rodents (Tullberg 1899, Landry 1957, Fleischer 1973). Even though this system is not well studied, separated ear bones are typical for mammals and may represent the plesiomorphic condition of Rodentia. Thus, the linkage of the malleus and incus is presumably derived (see Landry 1999). The functional advantage over the ancestral condition is not clear.

\section{Rostral nasal complex}

This region shows significant derived character conditions, presumably caused by a functional shift of tactile exploration from the hairless skin of an extended rostrum to the gnawing teeth (Ade 1999). Data so far indicate that the outer nasal cartilage (Fig.3A,B, top line) to transformed from a rather stable, ring-like enclosure of the nasal openings a more mobile construction in Hystricognathi (Mess 1997, 1999a, Mess et al. 2001). Only the Bathyergidae retain some plesiomorphic features of Rodentia, suggesting an early dichotomy between them and the other hystricognaths (Mess 1997, 1999a). As a first step, the associated skin exhibits an evolutionary transformation on the stem lineage of Hystricognathi. The tactile narial pads (Fig.3A, bottom line) of Rodentia and Lagomorpha (Glires) are reduced to tiny knobs (Fig.3B, bottom line) located inside the narial opening (Ade 1998, 1999). Thus, the rostral nasal area lost its tactile ability (Ade 1998). Obviously, the evolution of the skin evoked further evolutionary steps in the cartilaginous skeleton, a fact that is not often the case in mammals or that at least is only occasionally documented. Since hystricognaths lost an important instrument for searching invertebrates in the ground, the above mentioned evolutionary transformations in hystricognaths are regarded to be associated with the switch from omnivorous to herbivorous nutrition (Ade 1999, Mess 1999a). It expedited their radiation when open ecosystems and grasslands arose during the Earth history (Mess et al, 2001).

Incisor enamel microstructure and molar arrangement

The rodent gnawing teeth, classified as ever-growing dI2 (Luckett 1985), provided an enormous potential 
A

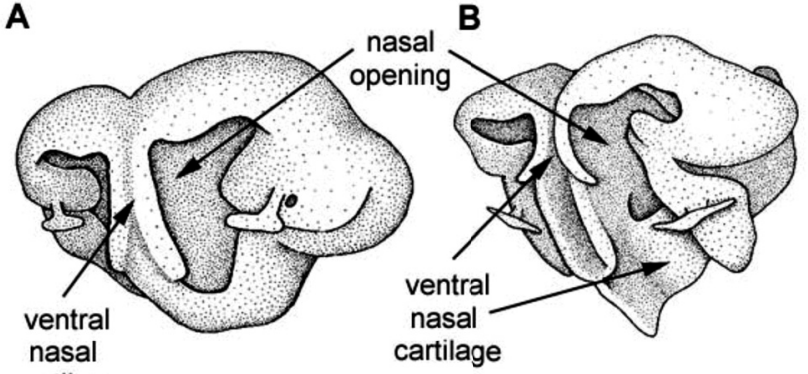

cartilage

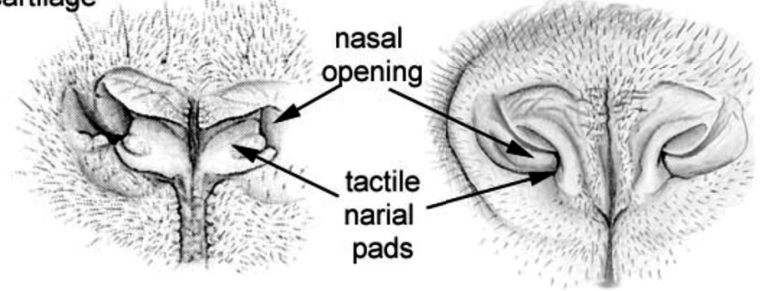

Fig.3. The rostral nasal region. (A) The ancestral condition of Rodentia. The outer nasal cartilage (above) forms a ring-like enclosure of the nasal openings. The associated skin (below) possesses the narial pads with tactile ability. (B) The derived state in Hystricognathi. The nasal cartilage (above) transformed to a more mobile construction and the narial pads are reduced to tiny knobs at the inside of the narial opening (below). As a result, the rostral nasal area lost its tactile ability. Derived from Mess (1997, 1999a), Ade (1998) and Mess et al. (2001).

for the exploration and manipulation of the environment (Ade, 1999). The incisors have a doubled layer of enamel only on the front side (Martin 1999). The inner layer, consisting of the Hunter-Schreger bands (HSB) with layers of crystalline prisms among an interprismatic matrix (IPM), differs among rodents (Martin 1999). Hystricognathi, Ctenodactylidae and Pedetidae have multiserial HSB with an angular arrangement of the IPM to the prism long axes (Martin 1993, 1994). This condition is regarded as an adaptation that strengthens the enamel and provides a higher wear resistance (Pfretzschner 1988). It evolved from an unspecialized pauciserial pattern of the last common ancestor of Rodentia, and is convergent with HSB in other extant rodents such as murids (Martin 1993). Though the multiserial type is not exclusive for hystricognaths, it evidently represents an important character transformation to use a variety of plant species and parts including hard material, and may be a key for understanding hystricognath radiation (Mess et al., 2001). In addition, the hystricognath molars have lophate structures with crests instead of cusps, suggesting a marked herbivorous component in the diet (Mess et al. 2001). Several parallel transformations have been taken place with regard to the macroscopic form of the cheek teeth: starting from relatively flat, low crowned or brachydont ones, beginning in the Oligocene many clades evolved high crowned or hypsodont forms that are often rootless or ever-growing (see Mess et al. 2001). These tooth forms are essential to successful use plants with high fiber content such as grasses, which are often siliceousrich too, and may be a key factor to occupy the extended grasslands that arose from the Miocene onwards (Mess et al. 2001). In addition, the presence of animals that were able to utilize grasses may have limited the dimension of the world's grasslands.

\section{Inner organs}

Several features associated with the inner organs are assumed to be significant for Hystricognathi. However, most of these systems are not well studied and the variety of characters within rodents is too poorly understood to allow sufficient conclusion on the phylogenetic value. For instance, this is the case for the cranial arterial pattern (Bugge, 1985) or traits in regard to mycology of the locomotors system (Woods and Hermanson, 1985). Even though the diversity of conditions is likewise not easy to interpret, Landry (1999) listed two features in his new classification: citing Gorgas (1967), the gut includes a colon with muscular folds that project into the lumen and increase the surface area for absorption, and a caecum with laterally thickened muscular bands. Second, as established by Tullberg (1899), Dathe (1937), Landry (1957) and George (1993), there is a sacculus urethralis, forming a bladder-like extension from the cavity of the glans penis upon erection and protruding beyond the penis tip (ctenodactylids have a "reduced" sacculus, whatever this means for systematics). The functional significance is unresolved. Finally, recent analysis on the lung anatomy and systematics (Wallau et al. 2000) indicated several derived character conditions: an asymmetry evolved with the left lung dominating and lobed (shared with ctenodactylids) and the left lung possesses an eparterial bronchus as well as a ventral lobe (synapomorphic for hystricognaths). The authors did not refer to functional implications. However, species that live in burrows or tight places tend to have more lobed lungs (Steven F. Perry, pers. comm.). In addition, the results derived from the lung structures indicated a dichotomy between the Bathyergidae and the other Hystricognathi (Wallau et al. 2000), likewise to the rostral nasal skeleton.

\section{Reproductive strategy}

Compared with the altricial reproductive mode as the ancestral or plesiomorphic condition of Rodentia, Hystricognathi are derived and possess a precocial strategy that is characterized by long gestation periods, an advanced developmental status of the newborns with open eyes, full fur and sensory and locomotion activeness, as well as a generally slow development towards the adult (Mess et al. 2001). Thus, hystricognaths established a K-strategy of reproduction when compared to the ancestral rodent's condition. This strategy is shared with Ctenodactylidae and may have been evolved in their common stem lineage. Using the domestic guinea pig as a model (Künkele et al. 2000 ), precociality is regarded as an adaption to reproduce with an efficient energy budget such that the mother's additional energy demand per day and the total costs for reproduction are lower than in altricial rodent species. This strategy allows reproducing under harsh or unstable conditions (see Mess et al. 2001).

\section{Placentation and the fetal membranes}

Structures associated with the chorioallantoic placenta and the other fetal membranes also provide im- 
portant characters. Although such features were briefly mentioned in the traditional classification of Tullberg (1899), they were in general neglected in the phylogenetic systematics. At first Patrick Luckett (1985) incorporated these systems within a phylogenetic context to rodent systematics. He mentioned three characters as derived for Hystricognathi: an invasive or superficial implantation, the fibrovascular ring as a capillary system in the attachment area of the visceral yolk sac and a subplacenta as a specialized region within the placental disc (Luckett 1985). However, the study included only 8 species of hystricognaths, often without proper data on the ultrastructure and the course of ontogeny. Important taxa that may represent ancient conditions of the group were not known at that time. Moreover, the character polarity was achieved in comparison to a hypothetical pattern that was regarded as ancient for eutherian mammals and was difficult to understand. Thus, own investigations in the last years included additional hystricognaths with special reference to species that may possess ancient character states by means of modern ultrastructural and immunohistochemical techniques as well as by applying more comprehensive computer based analyses of character evolution. In particular, maximum parsimony analyses on the basis of published results of other systems were used, because the placenta provided too few characters for independent cladistic approaches and - due to the time-consuming methods - there are large amounts of missing data (Mess 2003, Mess \& Carter 2006).

The following list of derived character states is consistent with the monophyly of Hystricognathi:

1 . The chorioallantoic placenta has a ring-shaped organization, characterized by inner areas for the feto- maternal exchange processes, associated with a radial flow of the maternal blood, and outer regions to sample the mother's blood (Fig.4; Mess 1999b, 2001, 2003). This arrangement is regarded to optimize the capacity for passive diffusion (Mess, 2001).

2. Allied is the pattern of placental development with proliferating trophoblast cells positioned at the outer margin of the placenta that follows bands of fetal mesenchyme towards the fetomaternal exchange areas inside (Mess 2007a,b).

3. A subplacenta (Fig.5), characterized by 18 shared features, occurred as a specialized region responsible for placental invasion (Mess 2003, 2007a,c, Mess et al. 2007).

4. Finally, the fibrovascular ring is confirmed by a wider taxa sampling (Mess 2005) and the completely inverted yolk sac facilitates substance exchange with the main placenta (Mess 2007c,d, Mess et al. 2008).

All things considered, a mode of placentation and reproduction in general is indicated that does not demand excessive additional energy intake by the mother and is in accordance with her low energetic diet (see Mess et al. 2001).

\section{CONCLUSIONS}

In summary, Hystricognathi possess major character transformations that represent prerequisites for their successful radiation at the time when open ecosystems and grasslands evolved during Earth history.

As a main result, structures associated with placentation show a high proportion of derived character conditions, in addition to the likewise derived precocial reproductive strategy.
A maternal arteries

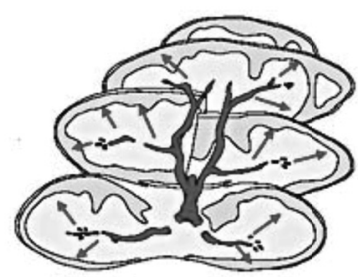

-

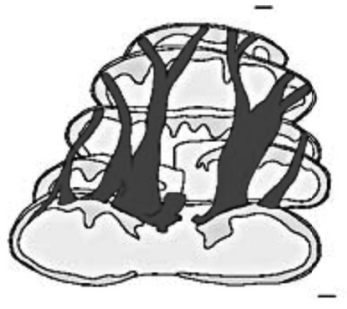

B maternal veins
C fetal arteries
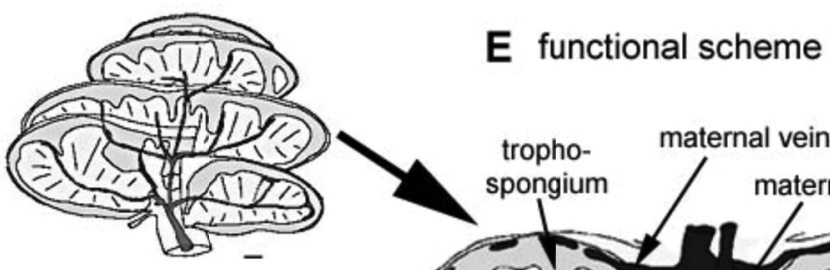

trophospongium
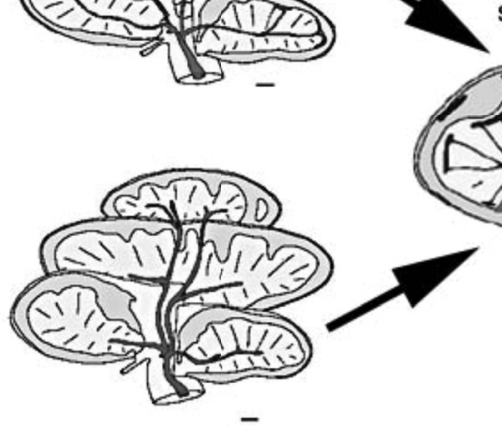

D fetal veins

Fig.4. (A-D) Chorioallantoic placentation in Hystricognathi, established for an advanced stage of Petromus. (D) Reconstructions. Each blood system is shown in one placental half. (E) Functional scheme. The placenta has a ring-shaped organization with inner areas for the fetomaternal exchange processes, the labyrinth, and outer regions to sample the mother's blood, the trophospongium. The later also served as growing zones for the placental disk. The revealed arrangement is derived within Rodentia, evolved on the stem lineage of Hystricognathi. 


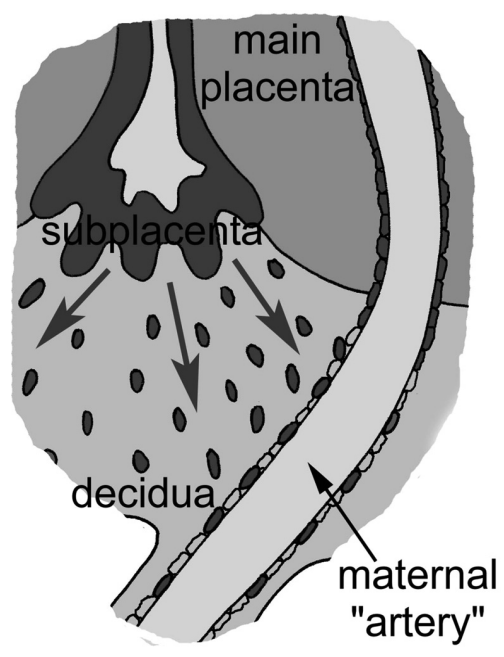

Fig.5. The subplacenta. A subplacenta, characterized by 18 shared features, is a specialized region within the placental disk. This unique structure evolved on the stem lineage of Hystricognathi. Trophoblast derived from the subplacenta is responsible for the replacement of the maternal arterial walls during placental invasion. The arrows indicate the migration routes of the invasive trophoblast (dark grey) to the arteries, where they substitute the endothelium (light grey).

Table 1. Morphological systems relevant for Hystricognathi

\begin{tabular}{|c|c|c|}
\hline System & Character & References \\
\hline Lower jaw & $\begin{array}{l}\text { Hystricognath lower jaw with pars } \\
\text { reflexa of } M \text {. pterygoideus lateralis } \\
\text { superficialis }\end{array}$ & $\begin{array}{l}\text { Tullberg 1899, Mess 1997, } \\
\text { Landry 1999, and other }\end{array}$ \\
\hline Skull base & $\begin{array}{l}\text { Rostral opening of the Fossa } \\
\text { pterygoidea }\end{array}$ & Tullberg 1899 \\
\hline Cranium & $\begin{array}{l}\text { Nasolacrimal duct ventromedial } \\
\text { incisor }\end{array}$ & Frahnert 1999, Landry 1999 \\
\hline Ear bones & $\begin{array}{l}\text { Maleus and incus fused or closely } \\
\text { joined }\end{array}$ & Tullberg 1899 \\
\hline Nose & Mobile rostral nasal skeleton & Mess 1997, 1999a \\
\hline Nose & $\begin{array}{l}\text { Lose of tactile ability in the rostral } \\
\text { skin }\end{array}$ & Ade 1998, 1999 \\
\hline Incisor & Enamel with multiserial HSB & Martin 1993, 1994 \\
\hline Lung & $\begin{array}{l}\text { Left lung dominating, lobed, } \\
\text { specialised }\end{array}$ & Wallau et al. 2000 \\
\hline Reproduction & Precocial reproductive strategy & Mess et al. 2001 \\
\hline Placenta & $\begin{array}{l}\text { Invasive, i.e. superficial implanta- } \\
\text { tion }\end{array}$ & Luckett 1985 \\
\hline Placenta & Subplacenta as specialised region & Luckett 1985, Mess 2007a \\
\hline Placenta & $\begin{array}{l}\text { Trophoblast invasion from sub- } \\
\text { placenta }\end{array}$ & Mess et al. 2007 \\
\hline Placenta & $\begin{array}{l}\text { Ring-shaped chorioallantoic } \\
\text { placenta }\end{array}$ & Mess 1999b, 2001, 2003 \\
\hline Placenta & $\begin{array}{l}\text { Growing zones at the placental } \\
\text { margin }\end{array}$ & Mess 2007a,b \\
\hline Placenta & Fibrovascular ring in yolk sac & Luckett, 1985; Mess, 2005 \\
\hline Placenta & $\begin{array}{l}\text { Additional, specific yolk sac } \\
\text { placenta }\end{array}$ & Mess $2007 \mathrm{c}, \mathrm{d}$ \\
\hline
\end{tabular}

Character conditions derived from various systems are regarded to be consistent with the monophyly of hystricognath Rodentia. These systems include skull bones and cartilage, the associated musculature, teeth, cranial and other soft tissues as well as the placenta, the other fetal membranes and reproductive biology. In particular, placental characters resulted as most important in this regard. The original references for each system are given.

Moreover, several evolutionary transformations of the rostral head region indicate a switch from omnivorous to herbivorous and fiber-rich nutrition.

Generally speaking, a mode of reproduction is indicated that does not demand excessive additional energy intake by the mother and is in accordance with her low energetic diet.

The analysis resulted in the reconstruction of a life-near picture of a pattern for the hystricognath stem species with high explanatory power in terms of changes in space and time and their interdependence with biodiversity.

In addition, the reconstruction of the hystricognath stem species pattern with the above revealed structural and functional characteristics creates an organismic view of theoretical concepts such as the strategy form of reproduction.

The creation of such integrative pictures of organismic biology may also find application in other fields of science.

Acknowledgements.- Alexander Haas and Thomas Kaiser invited me to present my data as a main lecture in the field of morphology at the DZG 2008 in Jena. Manfred Ade, Steven F. Perry, Marcello R. SánchezVillagra and Astrid Endler provided useful comments on a draft version of the text and Steven Perry helped with the English. Marylene Danto supply the illustration of the skull (Fig.2) and the illustrations of the outer nasal region in Figure 3 are from Manfred Ade. Stimulating discussions with various colleagues contributed to develop an integrative scenario on hystricognath evolution. I wish to thank all of them for their input.

\section{REFERENCES}

Ade M. 1998. Zur Evolution des Rhinariums der Glires: Eine Rekonstruktion auf phylogenetisch-systematischer Grundlage. Wissenschaft und Technik, Berlin. 150p.

Ade M. 1999. Macroscopic study on the rhinarium of the Lagomorpha: With special reference to the glires hypothesis. Mitt. Mus. Naturk. Berl., Zool. Reihe 75:191-216.

Brandt J.F. 1855. Beiträge zur nähern Kenntniss der Säugethiere Russland's. Mém. Acad. Imp. Sci. Peterbourg, Sci. Nat. (Zoologie et Physiologie), Sér.6, Vol.7, p.1-365.

Bugge J. 1985. Systematic value of the carotid arterial pattern in rodents., p.355-379. In: Luckett W.P. \& Hartenberger J.-L. (Eds), Evolutionary Relationships among Rodents. NATO ASI-Series 92, Plenum Press, New York.

Campbell K.E., Frailey C.D. \& Romero-Pittman L. 1996. The first Paleogene Fauna from the Amazon basin and its bearing on the first occurrence of rodents in South America. J. Vertebr. Paleontol. 16(Suppl.3):25A.

Catzeflis F.M., Hänni C., Sourrouille P. \& Douzery E. 1995. Molecular systematics of hystricognath rodents: The contribution of sciurognath mitochondrial 12S rRNA sequences. Mol. Phylogenet. Evol. 4:357-360.

Ciochon R.L. \& Chiarelli A.B. 1980. Evolutionary Biology of the New World Monkeys and Continental Drift. Plenum Press, New York. 528p.

Dathe H. 1937. Über den Bau des männlichen Kopulationsorganes beim Meerschweinchen und anderen hystricomorphen Nagetieren. Morph. Jb. 80:1-65.

Fleischer G. 1973. Studien am Skelett des Gehörorgans der Säugetiere, einschließlich des Menschen. Säugetierk. Mitt. 21:131-239.

Flynn J.J. \& Wyss A.R. 1998. Recent advances in South American mammalian phylogeny. Trends Ecol. Evol. 13:449-454.

Frahnert S. 1999. Morphology of the Glires Ancestral Rostral Cranium and its implications for the Monophyly of this Clade. Mitt. Mus. Naturk. Berl., Zool. Reihe 75:229-246.

George W. 1993. The strange rodents of Africa and South America, p.119141. In: George W. \& Lavocat R. (Eds), The Africa-South America Connection. Clarendon Press, London.

Gorgas M. 1967. Vergleichend-anatomische Untersuchungen am MagenDarm-Kanal der Sciuromorpha, Hystricomorpha und Caviomorpha. Z. Wiss. Zool. 17:237-404. 
Huchon D., Catzeflis F.M. \& Douzery E.J.P 1999. Molecular Evolution of the Nuclear von Willebrand Factor Gene in Mammals and the Phylogeny of Rodents. Mol. Biol. Evol. 16:577-587.

Huchon D. \& Douzery E.J.P. 2001. From the old world to the new world: A molecular chronicle of the phylogeny and biogeography of hystricognath rodents. Mol. Phylogenet. Evol. 20:238-251.

Huchon D., Catzeflis F.M. \& Douzery E.J.P. 2000. Variance of molecular datings, evolution of rodents and the phylogenetic affinities between Ctenodactylidae and Hystricognathi. Proc. Roy. Soc. Lond. B 267:393402.

Jaeger J.-J., Denys C. \& Coiffait B. 1985. New Phiomorpha and Anomaluridae from the Late Eocene of North-West Africa: Phylogenetic Implications, p.567-588. In: Luckett W.P. \& Hartenberger J.-L. (Eds), Evolutionary Relationships among Rodents. NATO ASI-Series 92, Plenum Press, New York.

Künkele J. 2000. Energetics of gestation relative to lactation in a precocial rodent, the guinea pig (Cavia porcellus). J. Zool. 259:533-539.

Landry S.O. 1957. The interrelationships of the New and Old World hystricomorph rodents. Univ. Calif. Publ. Zool. 56:1-117.

Landry S.O. 1999. A proposal for a new classification and nomenclature for the Glires (Lagomorpha and Rodentia). Mitt. Mus. Naturk. Berl., Zool. Reihe 75:283-316.

Lavocat R. 1969. La systématique des Rongeurs hystricomorphes et la dérive des continents. C. R. Acad. Sci., Sér. D 269:1496-1497.

Lavocat R. 1980. The implications of rodent paleontology and biogeography to the geographical sources and origin of the platyrrhine primates, p.93-102. In: Ciochon R.L. \& Chiarelli A.B. (Eds), Evolutionary Biology of the New World Monkeys and Continental drift. Plenum Press, New York.

Luckett W.P. 1985. Superordinal and intraordinal affinities of rodents: Developmental evidence from the dentition and placentation, p.227276. In: Luckett W.P. \& Hartenberger J.-L. (Eds), Evolutionary Relationships among Rodents. NATO ASI-Series 92, Plenum Press, New York.

Luckett W.P. \& Hartenberger J.-L. 1985. Evolutionary relationships among rodents: comments and conclusions, p.685-712. In: Luckett W.P.\& Hartenberger J.-L. (Eds), Evolutionary Relationships among Rodents. NATO ASI-Series 92, Plenum Press, New York.

Maier W. \& Schrenk F. 1987. The hystricomorphy of the Bathyergidae, as determined from ontogenetic evidence. Z. Säugetierk. 52:156-164.

Martin R.D. 1990. Primate Origins and Evolution: A phylogenetic reconstruction. Chapman and Hall, London. 804p.

Martin T. 1993. Early Rodent Incisor Enamel Evolution: Phylogenetic implications. J. Mamm. Evol. 1:227-254.

Martin T. 1994. African origin of caviomorph rodents is indicated by incisor enamel microstructure. Paleobiology 20:5-13.

Martin T. 1997. Incisor enamel microstructure and systematics in rodents, p.163-175. In: Koenigswald W.v. \& Sander P.M. (Eds), Tooth Enamel Microstructure. Balkema, Rotterdam.

Martin T. 1999. Phylogenetic implications of Glires (Eurymylidae, Mimotonidae, Rodentia, Lagomorpha) incisor enamel microstructure. Mitt. Mus. Naturk. Berl., Zool. Reihe 75:257-273.

McKenna M.C. \& Bell S.K. 1997. Classification of Mammals above the Species Level. Columbia University Press, New York. 631p.

Mess A. 1997. Ontogenetische und phylogenetisch-systematische Studie zur Ethmoidal- und Orbitalregion der Hystricognathi (Rodentia). Wissenschaft und Technik, Berlin. 112p.

Mess A. 1999a. The rostral nasal skeleton of hystricognath rodents: evidence on their phylogenetic relationships. Mitt. Mus. Naturk. Berl., Zool. Reihe 75:19-35.

Mess A. 1999b. Plazentation von Petromus typicus, ein Beitrag zur Reproduktionsbiologie und evolutiven Differenzierung der Hystricognathi. Courier Senckenberg 215:153-157.

Mess A. 2001a. Evolutionary differentiation of placental organisation in hystricognath rodents, p.279-292. In: Denys C., Granjon L. \& Poulet A. (Eds), African Small Mammals. IRD Éditions, Collection Colloques et Séminaires, Paris.
Mess A. 2003. Evolutionary transformations of chorioallantoic placental characters in Rodentia with special reference to hystricognath species. J. Exp. Zool. (Comp. Exp. Biol.) 299 A, 78-98.

Mess A. 2005. The fibrovascualar ring: A synapomorphy of hystricognath Rodentia newly described in Petromus typicus and Octodon degus. Belg. J. Zool. 135:31-38.

Mess A. 2007a. Development of the chorioallantoic placenta in Octodon degus: A model for growth processes in caviomorph rodents? J. Exp. Zool. (Mol. Dev. Evol.) 308 B:371-383.

Mess A. 2007b. The Guinea Pig Placenta: Model of placental growth dynamics. Placenta 28:812-815.

Mess A. 2007c. Chorioallantoic and yolk sac placentation in the dassie rat Petromus typicus and its bearing to the evolution of hystricognath Rodentia. Placenta 11:1229-1233.

Mess A. 2007d. The subplacenta in Octodon degus and Petromus typicus: Two hystricognath rodents without significant placental lobulation. J. Exp. Zool. (Mol. Dev. Evo.l) B 308:172-188.

Mess A. \& Carter A.M. 2006. Evolutionary transformations of fetal membrane characters in Eutheria with special reference to Afrotheria. J. Exp. Zool. (Mol. Dev. Evol.) B 306:140-163.

Mess A., Mohr B. \& Martin T. 2001. Transformations in the stem species pattern of hystricognath Rodentia and the climatic change in the Eocene to Late Oligocene time interval. Mitt. Mus. Naturk. Berl., Zool. Reihe 77:193-206

Mess A., Zak N., Kadyrov M., Korr H. \& Kaufmann P. 2007. Caviomorph placentation as a model for trophoblast invasion. Placenta 11:12341238.

Miglino M.A., Franciolli A.L.R., Oliveira M.F. de, Ambrósio C.E., Bonatelli M., Fernandes Machado M.R. \& Mess A. 2008. Development of the inverted yolk sac in three species of caviids (Rodentia, Caviomorpha, Caviidae). Placenta 29:748-752.

Nebdal M.A., Allard M.W. \& Honeycutt R.L. 1994. Molecular systematics of hystricognath rodents: Evidence from the mitochondrial $12 \mathrm{~S}$ rRNA gene. Mol. Phylogenet. Evol. 3:206-220.

Nedbal M.A., Honeycutt R.L. \& Schlitter D.A. 1996. Higher-level systematics of rodents (Mammalia, Rodentia): Evidence from the mitochondrial 12S rRNA gene. J. Mamm. Evol. 3:201-237.

Patterson B. \& Wood A.E. 1982. Rodents from the Deseadan Oligocene of Bolivia and the relationships of the Caviomorpha. Bull. Museum Comp. Zool. 149:371-543.

Pfretzschner H.U. 1988. Structural reinforcement and crack propagation in enamel, p.133-143. In: Russel D.E., Santoro J.-P. \& Sigogneau-Russell D. (Eds), Teeth Revisited. Mem. Mus. Nat. Hist. Nat. C 53:1-462.

Rinderknecht A. \& Blanco R.E. 2008. The largest fossil rodent. Proc. Biol. Sci. 275 : 923-928.

Sánchez-Villagra M.R., Aguilera O. \& Horovitz I. 2003. The anatomy of the world's largest extinct rodent. Science 301:1708-1710.

Starck D. 1995. Teil 5: Säugetiere, p.1-694. In: Starck D. (Ed.), Lehrbuch der Speziellen Zoologie 2. Wirbeltiere. Fischer, Jena.

Sullivan J. \& Swafford D.L. 1997. Are guinea pigs rodents? The importance of adequate models in molecular phylogenetics. J. Mamm. Evol. 4:77-86.

Tarling D.H. 1980. The geologic evolution of South America with special reference to the last 200 million years, p.1-41. In: Ciochon R.L. \& Chiarelli A.B. (Eds), Evolutionary Biology of the New World Monkeys and Continental drift. Plenum Press, New York.

Tullberg T. 1899. Ueber das System der Nagethiere: Eine phylogenetische Studie. Akademische Buchdruckerei, Uppsala. 514p.

Vucetich M.G. \& Verzi D.H. 1999. Changes in diversity and distribution of the caviomorph rodents during the Late Cenozoic in Southern South America. Quarternary of South America and Antarctic Peninsula 12:207-223.

Vucetich M.G., Verzi D.H. \& Hartenberger J.-L. 1999. Review and analysis of the radiation of the South American Hystricognathi (Mammalia, Rodentia). C. R. Acad. Sci. II A 329:763-769.

Wallau B.R., Schmitz A. \& Perry S.F. 2000. Lung morphology in rodents 
(Mammalia, Rodentia) and its implication for systematics. J. Mamm. Biol. 246:228-248.

Waterhouse G.R. 1848. A Natural History of the Mammalia. Vol.2, Rodentia. Hippolyte Bailliere, London. 500p.

Wilson D.E. \& Reeder D.M. 2005. Mammal Species of the World: A taxonomic and geographic reference. Johns Hopkins University Press, Baltimore. 743p.

Winkler A.J. 1994. The middle/upper Miocene dispersal of major rodent groups between southern Asia and Africa, p.173-184. In: Tomida Y, Li C.-K. \& Setoguchi T. (Eds), Rodent and Lagomorphs Families of Asian Origins and Diversification. National Science Museum Monogr., Tokyo.
Wood A.E. \& Patterson B. 1959. The rodents of the Deseadan Oligocene of Patagonia and the beginnings of South American rodent evolution. Bull. Mus. Comp. Zool. 120:279-428.

Woods C.A. \& Hermanson J.W. 1985. Myology of Hystricognath Rodents: An analysis of form, function, and phylogeny, p.515-548. In: Luckett W.P. \& Hartenberger J.-L. (Eds), Evolutionary Relationships among Rodents. NATO ASI-Series 92, Plenum Press, New York.

Wyss A.R., Flynn J.J., Norell M.A., Swisher C.C., Charrier R., Novacek M.J. \& McKenna M.C. 1993. South America's earliest rodent and recognition of a new internal of mammalian evolution. Nature 365: 434-437. 